\title{
O RETORNO DO REI: AS MUTAÇÕES NA CLÁSSICA DIVISÃO DOS PODERES PELA JUDICIALIZAÇÃO DAS RELAÇÕES SOCIAIS E ATIVISMO JUDICIAL
}

\section{THE KING'S RETURN: THE MUTATION IN CLASSICAL DIVISION OF POWERS BY JUDICIALIZATION OF SOCIAL RELATIONS AND JUDICIAL ACTIVISM}

\author{
Kelly de Souza Barbosa ${ }^{1}$ \\ Ricardo dos Reis Silveira ${ }^{2}$
}

\section{RESUMO}

A separação dos poderes é um dos aspectos mais fortes do constitucionalismo contemporâneo, máxime por racionalizar o exercício do poder estatal. No Brasil, a Constituição de 1988 prevê como cláusula pétrea a tripartição dos poderes. Todavia, verifica-se uma alteração nos paradigmas especialmente em nível de jurisdição constitucional, por meio dos fenômenos da judicialização e do ativismo judicial, devido a atuação interventiva do Judiciário nas funções precípuas dos outros poderes. Utilizando o método dedutivo e descritivo e pesquisas bibliográfica e documental, procurou-se apontar os malefícios que a atuação invasiva do Judiciário causa ao equilíbrio funcional entre os poderes e a democracia.

Palavras-chaves: Tripartição dos poderes; Desequilíbrio; Jurisdição Constitucional; Judicialização; Ativismo Judicial.

\begin{abstract}
Separation of powers is one of strongest aspects of contemporary constitutionalism, mostly to rationalize the exercise of state power. In Brazil, the 1988 Constitution provides as entrenchment clause to tripartition of powers. However, there is a change in paradigms, especially at the level of constitutional jurisdiction, through the phenomena of judicialization and judicial activism because the intervention of the Judiciary in the primary functions of other powers. Using deductive and descriptive method, bibliographical and documentary research, we tried to point out the harms that the invasive action of the Judiciary causes to the functional balance between the powers and democracy.
\end{abstract}

Keywords: Tripartition of powers; Instability; Constitutional jurisdiction; Judicialization; Judicial Activism.

\section{INTRODUÇÃO}

\footnotetext{
${ }^{1}$ Mestranda em direitos coletivos e cidadania pela Universidade de Ribeirão Preto - UNAERP, São Paulo (Brasil). Email:

${ }^{2}$ Doutor e Mestre em Filosofia e Metodologia das Ciências pela Universidade Federal de São Carlos - UFSCAR, São Paulo (Brasil). Bacharel em Ciências Jurídicas pela Universidade Federal de Ouro Preto - UFOP, São Paulo (Brasil). Advogado. E-mail:
} 
A clássica tripartição dos poderes de Montesquieu vem sofrendo um tipo de mutação, sobremaneira pela invasão do Judiciário em searas as quais não frequentava. Esse movimento inicia-se, especialmente, na segunda metade do século XX nos E.U.A. ${ }^{3}$, mas já no final do século passado e início do presente, difundiu-se para várias regiões do planeta.

A jurisdição constitucional apresenta duas novas manifestações do Poder Judiciário no contexto político, jurídico e social, a primeira relacionada à judicialização das relações políticas e sociais e asegunda marcada pelo intervencionismo nos outros poderes, chamada de ativismo judicial.

A judicialização é própria do desenho constitucional e institucional brasileiro, máxime com a promulgação da Constituição da República Federativa de 1988 (CF/88) que ampliou significativamente o rol de direitos individuais, sociais, coletivos e difusos abrangidos por ela. E dado o princípio da inafastabilidade da jurisdição (artigo $5^{\circ}$, inciso $\mathrm{XXXV}, \mathrm{CF} / 88$ ), foi possibilitado ao Judiciário manifestar-se imperativamente sobre uma gama consideravelmente alta de questões.

Esses dois fenômenos causam relevante mutação na fisionomia clássica da separação dos poderes. O ativismo judicial é fortalecido com a inércia ilegítima (e em algumas situações proposital) doPoder Executivo e Legislativoem suas funções ímpares, de tal sorte que os cidadãos procuram amparo no Judiciário para resolverem litígios que nem sempre deveriam ser objeto deapreciação judicial, mas sim de solução administrativa ou proposta de lei.

Considerando as controvérsias do intervencionismo judicial decorrente da ampla judicialização das relações sociais edo ativismo,foi desenvolvido o presente artigoem quatro capítulos utilizando o método dedutivo-descritivo e a pesquisa bibliográfica e documental.

No primeiro capítulo serão abordadas as principais características da formação do Estado Democrático de Direito. No segundo capítulo contextualiza-se a jurisdição constitucional brasileira pós-1988 e no terceiro capítulo a judicialização das relações sociais. Por fim, o quarto capítulo é dedicado ao assunto principal do artigo que é o ativismo judicial e

\footnotetext{
${ }^{3}$ É marcante, nesse aspecto, a decisão tomada pela Suprema Corte norte americana no caso Brown v. BoardofEducationof Topeka de 1954, que mudando entendimento anterior (caso Plessy v. Ferguson de 1896) proíbe a discriminação racial em escolas daquele país, botando em xeque o princípio daequal, butseparet, revisando o entendimento acerca da décima quarta emenda à constituição daquele país. $\mathrm{E}$, mais do que isso, o tribunal toma posição proativa em relação à política educacional do governo.
} 
as consequências desta atuação na fisionomia da separação dos poderes na conjuntura estatal brasileira.

\title{
2FORMAÇÃO DOESTADO DEMOCRÁTICO DE DIREITO
}

Desde o século XVII, com as revoluções inglesas, passando pela independência das colônias do norte da América, Revolução Francesa e obras de relevantes pensadores como Montesquieu, Locke, os autores dos artigos que compõe o Federalista, a técnica da divisão dos poderes, com a consequente implementação de mecanismos de controle recíproco entre eles estão consignados no texto das principais constituições do mundo.

O Barão de Montesquieu (1689-1755) viveu no período em que reinava o governo monárquico, sem qualquer limitação e fiscalização das ordens reais; neste contexto histórico elaborou a célebre Teoria da Tripartição dos Poderes.Segundo ele:

\begin{abstract}
Quando, na mesma pessoa ou no mesmo corpo da magistratura, o Poder Legislativo está reunido ao Poder Executivo, não existe liberdade; porque se pode temer que o mesmo monarca ou o mesmo senado crie leis tirânicas para executá-las tiranicamente. Tampouco existe liberdade se o poder de julgar não for separado do Poder Legislativo e do Executivo. Se estivesse unido ao Poder Legislativo, o poder sobre a vida e a liberdade dos cidadãos seria arbitrário, pois o juiz seria legislador. Se estivesse unido ao poder Executivo, o juiz poderia ter a força de um opressor. (2000, p.168)
\end{abstract}

Conquanto o poder governamental esteja tripartido em Legislativo, Executivo e Judiciárioo uso de cada parcela do poder no âmbito de sua competência pode se concentrar e retornar ao status arbitrário. Para evitar essa situação, a teoria americana checkand balances estabelece que além das funções típicas de cada poder, cada um deles terá uma fração reduzida das atividades dos outros tidas como funções atípicas.

Aprofundando a legalização da organização e limitação do poder do Estado e a proteção dos direitos fundamentais é criada uma carta legal, intitulada de Constituição, dotada de soberania e supremacia legal, decorrente de sua rigidez (Estado Constitucional).

Unindo o Estado Social e o Estado de Direito Constitucional tem-se o surgimento do Estado Democrático de Direito, consagrado no Brasil no artigo $1^{\circ}$, caput da Constituição da República Federativa de 1988 (CF/88).Além da participação popular elevada ao mais alto patamar (governo do povo), há uma mudança na aplicação do direito, pois "a lei veio a ter, 
sobretudo, a função de concretização dos valores socialmente estabelecidos nas constituições e, assim sendo, a de implementar reais modificações. " (JUNIOR MORAES, 2007, p.129)

A separação de poderes passa a ser um dos princípios fundamentais do Estado Democrático de Direito, sendo consagrado como cláusula pétrea (ou seja, é vedada emenda constitucional tendente a diminuí-lo ou aboli-lo), conformeartigo $60, \S^{\circ}$, inciso III da $\mathrm{CF} / 88$.

Conquanto oLegislativo, Executivo e Judiciáriotenham funções atípicas, a interferência desmedida de um poder na função típica do outro desequilibra a harmonia entre eles, a autonomia funcional e desestabiliza a segurança jurídica (artigo $2^{\circ}$ da CF/88).

Notadamente, com o locupletamento do Poder Judiciário por demandas de temáticas diversas e, principalmente, contra os outros poderes (seja pela má prestação do serviço público ou a total omissão), os juízes decidem cada vez mais sob fundamentos políticos; fatoresse prejudicial à ordem constitucional democrática.

No Brasil os governantes e parlamentares são democraticamente eleitos pelo voto popular, enquanto os magistrados ingressam na carreira por meio de concurso público de provas e títulos ou pelo quinto constitucional (artigo 93, inciso I e artigo 94 da CF/88), para a função jurisdicional (e não legislativa e/ou executiva).

Desta forma, embora o magistradonão possa se escusar de responder a uma demanda corretamente encaminhada, conforme o artigo $5^{\circ}$, inciso $\mathrm{XXXV}$ da $\mathrm{CF} / 88$, ele não goza de expressaautorização popularpara alterar bruscamente o teor da lei e influenciar indiscriminadamente no orçamento público, no ato de apreciação da lide. Nos dizeres de Barroso “nunca é demais lembrar que o poder emana do povo, não dos juízes. ”(2016, p.396)

Assim, a jurisdição constitucional brasileira(máxime o ativismo judicial) deve ser analisada com parcimônia frente à necessidade da concretização dos direitos fundamentais, a descrença dos cidadãos nos seus representantes devidamente eleitos e a ampliação da atividade jurisdicional.

\section{JURISDIÇÃO CONSTITUCIONAL BRASILEIRA}

Após vinte e um "anos de chumbo" o Brasil concebe em 1988 uma nova carta constitucional, carinhosamente apelidada por Ulysses Guimarães de Constituição Cidadã, que 
busca restabelecer a democracia e o respeito aos direitos fundamentais, além de inovar em campos do direito, como com o reconhecimento do direito ambiental.

Durante o período de 1964-1985 os parlamentares e magistrados encontravam-se reprimidos e submetidos aos Atos Institucionais e as vontades políticas dos administradores, in casu,os militares que governaram o país, colecionando inúmeras atrocidades contra os direitos fundamentais do cidadão e a ordem política do Estado.Frisa Bechara e Rodrigues:

\begin{abstract}
Com efeito, não se estabeleceu limite ao exercício do Poder Executivo, nem se respeitou a autonomia dos poderes, pois o Legislativo e o Judiciário viram-se submetidos ao Executivo, controlado pelos militares, além de terem de obedecer ao disposto nos Atos Institucionais e seus complementos assim como à Lei de Segurança Nacional. (2015, p.599)
\end{abstract}

Os referidos autores nas balizas do relatório da Comissão da Verdade ressaltam que durante o golpe militar "os magistrados que permaneceram como tais no Poder Judiciário frequentemente eram parte da estrutura militar e tinham clareza das circunstâncias em que haviam sido ungidos, interpretando e aplicando o ordenamento em consonância com o regime militar”. (2015, p. 601)

Diante disto a atual Constituição ampliou os direitos humanos e os direitos fundamentais, assim como, as garantias do Judiciárioa fim de torná-lo mais forte e independente para que viabilizeas pessoasuma proteção maior e mais efetiva de seus direitos, sem qualquer interferência política arbitrária.

Leal e Bolesina (2012, p.386-387) destacam dois aspectos técnicos que autorizam essa atuação mais relevante do Poder Judiciário: (a) a constitucionalização dos direitos fundamentais, impondo ao Judiciário o dever de zelar por esses direitos, mesmo que contrariando os interesses da maioria ${ }^{4}$, validando ou não atos e leis e (b) a missão mister do Judiciário, delegada pelo Estado Democrático de Direito, de garantir o direito e o pleno exercício da democracia e dos direitos fundamentais.

Neste contexto surge a jurisdição constitucional que "compreende o poder exercido por juízes e tribunais na aplicação direta da Constituição, no desempenho do controle de

\footnotetext{
${ }^{4} \mathrm{O}$ movimento contramajoritário do Judiciário decorre da necessidade da tutela estatal para resguardar os interesses das minorias pouco observados diante da preponderância dos interesses da maioria. Assim juízes (mister os ministros do Supremo Tribunal Federal) ampliam ou não o sentido da norma, sob fundamentos jurídicos de salvaguarda dos primeiros.
} 
constitucionalidade das leis e dos atos do Poder Público em geral e na interpretação do ordenamento infraconstitucional conforme a Constituição”. (BARROSO, 2016, p. 383)

Este último ponto, concernente à interpretação do ordenamento infraconstitucional conforme a Constituiçãoguarnece de questionamentos ferrenhos quando se está a analisar princípios, normas de sentido amplo e/ou vago, conceitos jurídicos indeterminados, hard casese, até mesmo, o uso da hermenêutica.

O magistrado ao aplicar a norma ao caso concreto deve atentar-se para o verdadeiro sentido dela, senão a sua interpretação poderá ser tão díspar da intenção precípua do legislador que o processo judicial ao invés de decidir a lide criará uma nova norma. Destarte, denotar-se-á na decisão vestígios políticos e de foro íntimo, ampliação da competência decisória, uma função magistral mais política que judicial e, por conseguinte, menos imparcial. Salienta Barroso:

\footnotetext{
Nas demais situações - isto é, quando não estejam em jogo os direitos fundamentais ou os procedimentos democráticos -, juízes e tribunais devem acatar as escolhas legítimas feitas pelo legislador, assim como ser deferentes com o exercício razoável de discricionariedade pelo administrador, abstendo-se de sobrepor-lhes sua própria valoração política. Isso deve ser feito não só por razões ligadas à legitimidade democrática, como também em atenção às capacidades institucionais dos órgãos Judiciários e sua impossibilidade de prever e administrar os efeitos sistémicos das decisões proferidas em casos individuais. (2016, p. 395-396)
}

Conquanto o Supremo Tribunal Federal seja o guardião da Constituição, isso não significa que seus ministros sejam experts em todas as matérias constitucionais e nas outras ciências correlacionadas ao fato analisado. Aliás,“o fato da última palavra acerca da interpretação da Constituição ser do Judiciário não o transforma no único - nem no principal - foro de debate e de reconhecimento da vontade constitucional a cada tempo." (BARROSO, 2016, p. 396)

Os magistrados possuem uma visão judicial sobre o assunto, por vezes dissonantes com a realidade e a técnica necessária para resolver a demanda, sobretudo quanto à gestão dos orçamentos públicos e os impactos de interpretações dotadas de generalidade e abstração (verbi gracia: precedentes, súmulas, orientações).

Não obstante o fortalecimento do amicuscuriae, das audiências públicase pareceres técnicos no cenário judicial, esses institutos são meramente consultivos (não vinculam). Logo, 
questões que melhor seriam apreciadas por outros órgãos são analisadas pelos juízes, que não dispõem da capacidade técnica e/ou institucional sobre a matéria. Além do mais existem osefeitos sistêmicos.

[O juiz] nem sempre dispõe das informações, do tempo e mesmo do conhecimento para avaliar o impacto de determinadas decisões, proferidas em processos individuais, sobre a realidade de um segmento econômico ou sobre a prestação de um serviço público. Tampouco é passível de responsabilização política por escolhas desastradas. (BARROSO, 2012a, p.30)

O juiz ao se pronunciar em uma demanda não possui a capacidade de prever os efeitos futurosque a sua decisão poderá causar na sociedade e no mundo jurídico, e caso sejam negativosnão se vislumbra mecanismos para responsabilizá-lo pelo seu posicionamento errôneo.

Ante o exposto, verifica-se uma antinomia judicial, pois ao mesmo tempo em que se busca manter o equilíbrio dos direitos fundamentais e da democracia pela interpretação da norma, há uma lesão frontal aos princípios da legalidade e da imparcialidade quando o sentido dela é abruptamente modificado.

Para a remediação deste impasse, Leal e Bolesina propõem uma jurisdição constitucional aberta, no qual os intérpretes da Constituição e a população - esta última quando provoca o Judiciário, pois, ao mesmo tempo em que pleiteia um direito fundamental em benefício próprio, questiona a sua efetivação pelos demais poderes -, se unem para fiscalizar a ordem constitucional.

\begin{abstract}
A abertura da jurisdição constitucional para a participação democrática no seu seio, aliada com a possibilidade da formação de intérpretes diversos do texto dos direitos fundamentais, além de afiar os compromissos constitucionais, valoriza o pluralismo e a coexistência em sociedade. Ao mesmo tempo, corrobora a legitimidade da jurisdição constitucional no exercício de defesa dos direitos fundamentais eda democracia, que tendem a serem aproximados, porém, agora com auxílio da participação popular como igual guardião dos valores constitucionais. (2012, p. 291292)
\end{abstract}

Tal solução não é pacífica e inúmeros são os questionamentos relacionados à jurisdição constitucional, mormente quanto ao ativismo judicial, sendo um campo fértil de análise científica. 
Além do ativismo judicial há outra vertente da jurisdição constitucional que permeia a mudança da concepção das funções do PoderJudiciárioe a consequente ampliação da capacidade institucional judicial, chamada de judicialização.

\section{JUDICIALIZAÇÃO}

Quando matérias de cunho eminentemente político, social e moral destinadas aos parlamentares e governantes são deliberadas exclusivamente pelos magistrados, tem-se a judicialização. Para Barroso (2016, p.384)“trata-se, como intuitivo, de uma transferência de poder para as instituições judiciais, em detrimento das instâncias políticas tradicionais, que são o Legislativo e o Executivo.

O referido autor aponta três causas para o surgimento deste fenômeno no mundo, são elas: (a) o reconhecimento da importância de um Judiciário forte e independente nas democracias modernas; (b) "a crise de representatividade e funcionalidade dos parlamentos em geral”; e que (c) “atores políticos, muitas vezes, preferem que o Judiciário seja a instância decisória de certas questões polêmicas, em relação às quais exista desacordo moral razoável na sociedade". (BARROSO, 2016, p. 385-386)

A Magna Carta de 1988 fortalece o Poder Judiciário ao constitucionalizar as garantias da irredutibilidade de subsídios, inamovibilidade e vitaliciedade dos magistrados (artigo 95, incisos I, II, III da CF/88) viabilizando uma maior imparcialidade e segurança nas decisões. E ao contemplar a autonomia orgânica-administrativa e financeira (artigos 99 e 168 da $\mathrm{CF} / 88$ ) da grande estrutura judicial nacional ${ }^{5}$ composta pelo Supremo Tribunal Federal, o Superior Tribunal de Justiça, a Justiça Federal e Estadual com seus respectivos juizados especiais, e os tribunais especializados (eleitoral, trabalhista e militar).

A robustez judicial auxilia na consubstanciação dos direitos fundamentais pelas pessoas, na estabilização da ordem econômica, na fiscalização da executividade dos deveres incumbidos pela Constituição ao Estado e na manutenção do convívio social.

Com a gradativa descrença popular nos representantes dos poderes Legislativo e Executivo em suas atividades específicas, têm-se o domínio progressivo da produção de

\footnotetext{
${ }^{5}$ Consoante os artigos 101, 104, 106, 111, 118, 122, 125 todos da CF/88.
} 
políticas públicas e de normas pelos tribunais na tentativa de suprir tais ineficiências. (SANTOS, 2015, p.194)

Não obstante a necessidade de respaldo judicial para as demandas sociais, a maior interferência do Judiciário na seara política desestabiliza a ordem política original calcada na Constituição e corrobora com a inércia dos demais poderes. Isso porque, ao invés de apenas compeli-los a realizarem seus deveresfins, o Judiciário de forma proativa emite seu parecer sobre a questão.

Essa situação ocasiona uma verdadeira crise de legitimidade, haja vista que decisões eminentemente políticas estão sendo tomadas via direta (sentenças e acórdãos) e reflexa (pareceres e pronunciamentos) por magistrados impulsionados pela crescente demanda e, ousa-se afirmar, pelas paixões sociais e midiáticas.

A propósito tem-se uma predileção dos próprios parlamentares para que o Judiciário decida sobre assuntos polêmicos e de alto clamor social a fim de evitar uma imagem ruim por parte do eleitorado. Foi o que aconteceu no julgamento da ADPF - Arguição de Descumprimento de Preceito Fundamental $n^{\circ} 54$ relacionada ao aborto de fetos anencefálicos (decisão necessária dotada de ativismo). Um verdadeiro dissenso à organização do Estado e a democracia.

Outro ponto é a elitização do debate com a judicialização, tendo em vista que para se ter acesso ao locusdo diálogo jurídico prescinde-se de domínio do instrumental jurídico (conhecimento técnico e treinamento específico), não acessíveis a generalidade de pessoas, deixando-as a margem da discussão e a espera de juízes providenciais. (BARROSO, 2016, p.393)

Além das causas supramencionadas, Barroso (2012a, p.24)também destaca como principais fatores da judicialização no Brasil: (a) a redemocratização do país, com o advento da Constituição Federal de 1988; (b) a constitucionalização abrangente, pois foram agregados ao texto matérias antes "destinadas ao processo político majoritário e para a legislação ordinária"; e (c) a adoção de um sistema de controle de constitucionalidade abrangente.

O movimento de constitucionalização dos direitos é uma transformação da política em direito, "na medida em que uma questão - seja um direito individual, umaprestação estatal ou um fim público - é disciplinadaem uma norma constitucional, ela se transforma,potencialmente, em uma pretensão jurídica, que podeser formulada sob a forma de 
ação judicial.” (BARROSO, 2012a, p.24) Portanto, com a constitucionalização da matéria a competência para discipliná-la é ampliada, tornando-atambém objeto de apreciação judicial.

$\mathrm{O}$ atual controle de constitucionalidade brasileiro "combina a matriz americana - em que todo o juiz e tribunal pode pronunciar a invalidade de uma norma no caso concreto - e a matriz europeia, que admite ações diretas ajuizáveis perante a corte constitucional. " (BARROSO, 2016, p. 387)Acrescenta Teixeira e Ravagnani

\begin{abstract}
O controle será objetivo, ou abstrato, quando tiver por finalidade a declaração de inconstitucionalidade do ato normativo visando à proteção da Constituição, e subjetivo, ou concreto, quando defender um interesse juridicamente protegido de alguém. O controle difuso é previsto na Constituição brasileira nos artigos 97, 102, inciso III, letras "a", "b" e "c" e 105, inciso II, letras "a" e "b". O controle concentrado é disciplinado pelo art., 102, I, letra "a", $\S 2^{\circ}$, e artigo 103, por meio da Ação Direta de Inconstitucionalidade e da Ação Declaratória de Constitucionalidade. (2015, p.394)
\end{abstract}

Conquanto nenhuma lesão ou ameaça de lesão possa ser afastada da apreciação do Judiciário, aliado ao extenso rol de direitos constitucionalizados e aos controles de constitucionalidade (difuso e concentrado), que expandem o exercício judicial, a latente usurpação das obrigações legislativas e executivas não pode prosperar desmedidamente. Barroso adverte:

\begin{abstract}
A judicialização constitui um fato inelutável, uma circunstância decorrente do desenho institucional vigente, e não uma opção política do Judiciário. Juízes e tribunais, uma vez provocados pela via processual adequada, não têm a alternativa de se pronunciarem ou não sobre a questão. Todavia, o modo como venham a exercer essa competência é que vai determinar a existência ou não do ativismo judicial. (2016, p. 387)
\end{abstract}

Observa-se no horizonte um processo paulatino e constante de restituição da centralização dos poderes sob o domínio uno, in $\operatorname{casu}_{s}$ do Judiciário, máxime na sua atuação ativista; sendo um verdadeiro retrocesso histórico político do controle do poder estatal.

Ao erigir o Judiciário como administrador supremo da vontade pública corre-se o risco de retornar ao antigo e ultrapassado paternalismo estatal, em que a figura do "pai" é assumida, desta vez, exclusivamente pelo Judiciário, que passa a ditar os direitos e liberdades dos "súditos" colocando-se acima do exercício da cidadania. (SANTOS, 2015, p.202) 
É indissociável a judicialização do atual sistema estatal brasileiro, sendo a sua manutenção necessária para a ordem social. Todavia ela deve ser amadurecida consoante os princípios basilares de organização do Estado (máxime os princípios da legalidade, separação dos poderes e democracia), para se evitar abruptas distorções funcionais, como pode ocorrer na atuação ativista.

\title{
5 ATIVISMO JUDICIAL
}

Barroso sintetiza que a judicialização é um fato, "uma circunstância do desenho institucional brasileiro" e o ativismo é"uma atitude, a escolha de um modo específico e proativo de interpretar a Constituição, expandindo o seu sentido e alcance ”. (2016, p. 390)

A conduta proativa do magistrado é importante para o andamento processual e para as decisões discricionárias destinadas ao desempenho da atividade organizacional (administração dos órgãos judiciais) e judicante.Neste contexto, Negrelly afirma que "o ativismo judicial pode ser considerado como uma postura participativa do magistrado na condução do processo judicial, sendo esta uma postura desejável para todo juiz e demais funcionários públicos. " (2010, p. 1419)

Quando o altruísmo judicial extrapola os limites delineados pelo ordenamento jurídico, máxime constitucional, têm-se um desequilíbrio funcional estatal, e o ativismo judicial tem uma concepção marcada pelo intervencionismo.

Inspirado pelos ensinamentos de Jamile B. Mata Diz e Gláucio Inácio da Silveira, Negrelly sintetiza a diferença entre as concepções sobre o ativismo judicial da seguinte forma:

\begin{abstract}
A distinção entre ambos os sentidos apontados é que no primeiro caso se fala sempre de momentos anteriores ou posteriores à decisão judicial, ou seja, são momentos do iter procedimental destinados à preparação do ato decisório ou à satisfação do direito reconhecido pelo pronunciamento judicial, enquanto, no segundo caso, se faz referência somente a sentença judicial prolatada pelo magistrado, pois é este o ato capaz de criar a norma jurídica concreta que será válida para a questão decidida e, em alguns casos, terá seus efeitos estendidos à toda sociedade. (2010, p.1419-1420)
\end{abstract}

Ressalta-se que além da sentença judicial, a edição de súmulas -principalmente as vinculantes -, orientações, precedentes normativos e jurisprudências também são atos que podem inovar no ordenamento jurídico, sem o crivo do PoderLegislativo. 
Barroso (2012a, p.26) explica que a expressão ativismo judicial nasce nos tribunais norte-americanos durante as atuações proativas da Suprema Corte, como nos casos em que se discutia a segregação racial (Dred Scott v. Sanford, 1857), a invalidação de leis sociais em geral (Era Lochner, 1905-1937) e no confronto entre o Presidente Roosevelt e a Corte, em que se mudou a orientação jurisprudencial contrária ao intervencionismo estatal (West Coast v. Parrish, 1937). Ele complementa:

\footnotetext{
A situação se inverteu completamente a partir da década de 50, quando a Suprema Corte, sob a presidência de Warren (1953-1969) e nos primeiros anos da Corte Burger (até1973), produziu jurisprudência progressista em matéria de direitos fundamentais, sobretudo envolvendo negros (Brown v. BoardofEducation, 1954), acusados em processo criminal (Miranda v. Arizona, 1966) e mulheres (Richardson v. Frontiero, 1973), assim como no tocante ao direito de privacidade (Griswold v. Connecticut, 1965) e 1965) e de interrupção da gestação (Roe v. Wade, 1973). (2012a, p.26)
}

O ativismo judicial está associado "a uma participação mais intensa do Judiciário na concretização dos valores e fins constitucionais, com maior interferência no espaço de atuação dos outros dois Poderes. " (BARROSO, 2016, p.389)

Georges Abboud restringe o fenômeno do ativismo judicial à discricionariedade judicial julgadora, “ ou seja, por meio dele, no Brasil, os pré-compromissos democráticos (Constituição e leis) são suspensos pelo julgador e substituído por sua subjetividade/discricionariedade” (2016, p.709), posição a qual se filia.

Embora Pimentel (2012) defenda que "o ativismo judicial no Brasil não configura nenhum extravasamento de juízes e tribunais no exercício das suas atribuições, mas sim traduz a sua indispensável e assumida participação na tarefa de dar concretude ao direito material"; no presente artigo busca-se uma visão menos romântica da atuação proativa do Judiciário, ressaltando-se os maléficos que o desequilíbrio entre os três poderes do estado pode causar no Estado Democrático de Direito.

A inércia do Poder Judiciário é rompida com a devida propositura da ação judicial, na qual os litigantes apresentam um fato controvertido acerca de um bem juridicamente protegido que precisa de uma solução técnica de um ente imparcial, dotado de força coercitiva, para que se restabeleça o bem-estar social e o convívio entre os demandantes. 
Não obstante a resposta judicial seja uma imposição constitucional, a forma como ela será formulada e apresentada deverá obedecer aos limites da mesma Carta Legal, a legislação e os princípios norteadores do Estado Democrático de Direito. Observa-se a postura ativista judicial quando o magistrado faz:

a) a aplicação direta da Constituição a situações não expressamente contempladas em seu texto e independentemente de manifestação do legislador ordinário; b) a declaração de inconstitucionalidade de atos normativos emanados do legislador, com base em critérios menos rígidos que os de patente e ostensiva violação da Constituição; c) a imposição de condutas ou de abstenções ao Poder Público, notadamente em matéria de políticas públicas. (BARROSO, 2012a, p.25-26)

Os magistrados integram o grande corpo jurídico do Estado impondo-se a eles os princípios da administração públicaprevistos no artigo 37, caput da $\mathrm{CF} / 88$, em especial o da legalidade. Preleciona o referido princípio que se por um lado o cidadão não está obrigado a fazer ou deixar de fazer algo, senão em virtude de lei, por outro, está totalmente restrita as atividades dos órgãos e servidores públicos ao mandamento legal.

As decisões judiciais e demais atos devem guardar o princípio da legalidade, de modo que a interpretação "não pode suprimir o governo da maioria, nem mesmo o Legislativo de modo a instituir uma ubiquidade que inexiste na Constituição. ” (SANTOS, 2015, p. 201)

Não significa que o julgador deve aplicar cegamente o texto normativo ao processo. Frisa-se que o intérprete deve adequar a lei ao contexto histórico e temporal da realidade vivida e as peculiaridades do caso concreto, porém sem inovar juridicamente e/ou distorcendo o teor legal. A recusa em ministrar a lei apenas será legítima se ela for inconstitucional.

Ativismo é toda decisão judicial que se fundamenta em convicções pessoais, senso de justiça do intérprete em detrimento da legalidade vigente - legalidade aqui entendida como legitimidade do sistema jurídico, e não como mero positivismo estrito ou subsunção ao fato do texto normativo. (ABBOUD, 2016, p. 710)

Por vezes o Judiciáriona função interpretativa estende os limites da norma constitucionaldevido o sentido vago, mormente quanto aos direitos fundamentais que necessitam de um preenchimento conceitual, seja porque o legislador constituinte não aprofundou a conceitualização ou por ausência de lei infraconstitucional regulamentadora. 
Mesmo entendimento quando se defronta com leis infraconstitucionais dotadas de excessiva abstração.

No entanto quando essa interpretação judicial resulta numa verdadeira inovação normativa, o princípio democrático é desmantelado. Os reais legitimados para a elaboração das leis são desconsiderados e a normatização judicial é preconcebida num ambiente particularizado que não corresponde com os anseios majoritários, próprios da lei.

O mesmo ocorre quando decisões judiciais, em casos individuais, influem em dotações orçamentárias desarticulando os direcionamentos públicos, sem uma prévia consulta aos governantes, de modo que interesses particulares sobressaem aos interesses coletivos.

A título de exemplo, conforme a pesquisa realizada por Ricardo Alves Silva nos anos de 2013 e 2014 foram contabilizadas, respectivamente, 310 e 524 ações judiciaisno Distrito Federal para entrega de medicamentos, um aumento de 59\% de um ano em relação ao outro. Em 2013 foram concluídos 269 processos para a procedência da entrega de medicamento por dispensa de licitação ou pelo PAD - JUD (Programa de Atendimento às demandas judiciais em saúde), e em 2014 foram 388 processos empenhados por dispensa de licitação e 89 pelo PAD-JUD. Desconsiderando os requerimentos extrajudiciais, o Executivo distrital empreendeu para a aquisição de medicamentos via judicial, no ano de 2013 R\$ 12.093.341,21(doze milhões, noventa e três mil, trezentos e quarenta e um reais e vinte e um centavos) e em $2014 \mathrm{R} \$ 22.651 .546,48$ (vinte e dois milhões, seiscentos e cinquenta e um mil, quinhentos e quarenta e seis reais e quarenta e oito centavos).

O pesquisador concluiupela defesa do ativismo judicial na seara sanitária, por ser um direito subjetivo do cidadão, constitucionalizado como absoluto e dever inescusável do Estado na garantia do mínimo existencial e da dignidade da pessoa humana.

Argumentos como a falta de capacidade orçamentária, a cláusula da reserva do possível, a interferência nas escolhas feitas por outros Poderes (Executivo e Legislativo) - Princípio da Separação dos Poderes, tudo isso é menor que a dignidade da pessoa humana que foi consubstanciada no direito à saúde e a vida. Fármaco com alto custo e que não está comtemplado nas listas de dispensação do Ministério da Saúde, das Secretarias estaduais, municipais e distritais, na maioria dos casos deve ser fornecido por ser direito subjetivo do cidadão e dever do Estado. (2015, p.78) 
Óbvio que as especificidades das minorias ${ }^{6}$ e os direitos fundamentais dos cidadãos devem ser considerados pelos juízes, mas também deve ser assegurada a manutenção do Estado Democrático de Direito e os limites institucionais, para a perpetuaçãoda ordem constitucional.

Silva também adverte que o Executivo distrital não está inerte ao problema (criação da CAMEDIS $^{7}$ ) e que tem verba suficiente para atender as demandas medicamentosas judiciais ou não, prescindo apenas de uma melhor gestão dos recursos.

Inegável as deficiências do Legislativo e Executivo, mas isso não significa que toda a sua composição esteja corrompida e desfavorávelà coletividade, como se pode observar pela CAMEDIS no Distrito Federal que nos meses de março a maio de 2015 solucionou 85\% das demandas de pedidos de medicamentos pela mediação. (SILVA, 2015, p.76)

A publicidade de decisões judiciais pela mídia politizada ofusca tendenciosamente o trabalho desenvolvido pelos outros poderes. Forçoso que os cidadãos se envolvam mais com as questões políticas e sociais, sobretudo na fiscalização de seus parlamentares e governantes, e busquem o pragmatismo na solução de conflitos de pequena monta.

Há urgência em se restabelecer a confiança do cidadão em solucionar seus conflitos (quando o caso concreto e a matéria permitir) nas outras instâncias de poder, haja vista a maior celeridade, diminuição de custo (um processo judicial tem um alto valor para as partes e para o Estado)e, até mesmo, uma melhor técnica (in casu, não jurídica) na decisão, além de aliviar a alta demanda judicial.Por exemplo, o pedido para asfaltar uma determinada rua será melhor avaliado pelo Executivoque considerará a viabilidade orçamentária com o departamento de engenharia, o atendimento público, do que pelo Judiciário, que não possui todos os dadosorçamentários e técnicos e a capacidade de administrar o bem público.

Os eleitores devem cobrar de seus parlamentares o desempenho eficaz das atividades para as quais foram eleitos, máxime a criação de legislações em prol da sociedade, e dos governantes a gestão transparente e correta do patrimônio público.

\footnotetext{
${ }^{6}$ Esclarece-se que a expressão minoria usado no texto não significa propriamente um quantitativo, mas sim grupos de pessoas com reduzida força política, verbi gracia, mulheres, índios, deficientes.

Explica Silva que a Câmara Permanente Distrital de Mediação em Saúde - CAMEDIS "foi instituída pela Portaria Conjunta $\mathrm{n}^{\circ}$ 01, de 26 de Fevereiro de 2013, através de ato emanado do Secretário de Saúde e do Defensor Geral do Distrito Federal, e que tem como principal atribuição fazer a mediação relativa às demandas por serviços de saúde oferecidos pelo Sistema Único de saúde (SUS) no Distrito Federal. A citada Portaria em seu artigo $3^{\circ}$ enumera os representantes de cada Órgão e suas funções, que se reúnem frequentemente para analisar as propostas de melhoria do sistema e o andamento dos trabalhos". (2015, p. 76)
} 
É um equívoco o cidadão entregar totalmente o dever de fiscalização de seus representantes ao Judiciário, que tem o método de atuação casuístico (e não de unidade social). Há a distorção da democracia participativa (que não se limita ao voto) com o sobrecarga dos juízos, embaraçando a apreciação hábil de demandas judiciais de alta complexidade.

Pimentel (2012) apresenta como principais exemplos de atuação ativista do Supremo Tribunal Federal: (a) decisão de constitucionalidade das pesquisas com células-tronco embrionárias ( $\mathrm{ADI}^{8 \mathrm{a}}$ 3.510/DF, Relator Ministro Carlos Britto); (b) vedação ao nepotismo nos três Poderes $\left(\mathrm{ADC}^{7 \mathrm{~b}} 12\right.$, Relator Ministro Carlos Britto; e RE ${ }^{7 \mathrm{c}} 579.951 / \mathrm{RN}$, Relator Ministro Ricardo Lewandowski) ${ }^{9}$; (c) proibição da prisão do depositário infiel, salvo nos casos de prestação alimentícia (HC's sd 87.585/TO, Relator Ministro Marco Aurélio e 92.566, Relator Ministro Marco Aurélio; RE's 349.703, Relator Ministro Gilmar Mendes e 466.343, Relator Ministro Cezar Peluso); (d) demarcação de terras indígenas na área Raposa/Serra do Sol (Petição no 3388/RR, Relator Ministro Carlos Britto); (e) aplicação do princípio da fidelidade partidária $^{10}$; (f) decisão pelo passe livre para deficiente no transporte coletivo (ADI 2.649/DF, Relatora Ministra Carmem Lúcia); (g) reconhecimento da união estável entre casais do mesmo sexo (ADI 4277/DF e ADPF 132/RJ).

Inquestionável a importância dessas decisões no contexto social brasileiro e seus impactos jurídicos e políticos. No entanto, elas sacrificaram princípios e diretrizes constitucionais da estrutura do Estado, a segurança jurídica, endeusaram magistrados e colaboraram com a apatia dos outros poderes.

O ativismo judicial brasileiro, conforme Abboud também pode ser detectado:

[Na] relativização (rectius: “'desconsideração”) da coisa julgada, atribuição de efeito vinculante para decisões e súmulas inconstitucionais;objetivação do controle difuso de constitucionalidade que, ontologicamente, é subjetivo; a ideia de que o destinatário da prova é o juiz e não o processo; a possibilidade de realizar motivação concisa limitando-se o órgão julgador a enumerar uma série de ementas de supostos casos paradigmas ou simples referência a enunciado de súmula vinculante; a alegação de mutação constitucional contra texto expresso da Constituição; a

8a,b,c,d Ação Direta de Inconstitucionalidade; Ação Direta de Constitucionalidade; Recurso Extraordinário; Habeas Corpus.

${ }^{9}$ Para tanto foi expedida a súmula vinculante número 13.

${ }^{10}$ Antes o Supremo Tribunal Federal defendia a inaplicabilidade do princípio da fidelidade partidária, mas com a mudança do seu entendimento, ele remeteu à matéria para o Tribunal Superior Eleitoral que é o competente para discipliná-la e, por conseguinte, foi editada a Resolução nº 22.610. (PIMENTEL, 2012) 
substituição, pelo Judiciário, da função constitucional legislativa, dentre outros. (2016, p. 720)

Não é a atribuição desmedida de efeitos vinculantes as decisões e interpretações distorcidas que o Judiciário terá força e legitimidade. Tais qualidades serão alcançadas com decisões fundamentadas rigidamente na Constituição que "é a verdadeira fonte de legitimidade das decisões do Judiciário, que não podem mais se basear em meras convicções pessoais de seus julgadores, mas em critérios racionais imputáveis e contidos no próprio texto constitucional." (ABBOUD, 2016, p. 731)

Outro ponto que robustece a atuação ativista judicial é o estado de coisas inconstitucional, em que qualquer questão fática-problemática ou política pública pode ser judicializada, conferindo "subterfúgio decisional para que o STF adentre em qualquer matéria, ainda que não haja previsão no texto constitucional para tanto." (ABBOUD, 2016, p. 741)

Frisa-se que embora o mecanismo de freios e contrapesos permita que um poder possua um pouco das atribuições do outro, essa benesse é limitada. Logo, para a manutenção da democracia e do Estado de Direito a tripartição dos poderes deve ser amplamente observada e respeitada.

Abboud faz alusão ao teorema dos dois corpos do rei de Ernest Kantorowicz para compreender a atuação judicial dos principais tribunais superiores. Segundo o teorema, o rei possui dois corpos autônomos inter-relacionados, sendo um natural tangível e finito e o outro político intangível e infinito (logo superior ao primeiro). Para o autor como os ministros do Supremo Tribunal Federal (STF) e do Superior Tribunal de Justiça (STJ) não se desvinculam da função jurisdicional, há uma espécie de dois corpos do julgador.

Ou seja, o STF, em vez de se preocupar em resguardar a Constituição por meio de sua jurisdição, passa a se identificar com a própria Constituição, consequentemente, passa a imaginar que está autorizado a proferir decisões que ultrapassem o próprio texto constitucional, que ao final, representa ele próprio. O mesmo é feito pelo STJ em relação à legislação infraconstitucional. (ABBOUD, 2016, p. 744-745)

A amalgama do julgador com a Constituição ou a lei permite decisões discricionárias baseadas em questões de foro íntimo, reduzindo a imparcialidade e a qualidade técnica. "Quando se decide discricionariamente, não se decide juridicamente" (ABBOUD, 2016, p. 745), e a democracia é desmantelada por decisões judiciais sem controle, pois se "o direito é 
aquilo que os Tribunais Superiores disserem que ele é” (ABBOUD, 2016, p. 743), a decisão nunca estará equivocada; o que é uma verdadeira falácia. O erro é inerente ao homem e como homens os magistrados também erram (frisa-se muito mais do que deveriam).

Para que a decisão apresente a resposta mais correta, mister a separação dos "dois corpos do julgador", eliminando-se a discricionariedade judicial, conforme o construtivismo de Dworkin, respeitando-se não apenas a Constituição e os procedimentos, mas a "coerência de princípios que compõem a integridade moral da comunidade. ” (ABBOUD, 2016, p.747)

\footnotetext{
A perspectiva de direito como integridade implica que toda a interpretação judicial tenha por finalidade uma descrição coerente da ordem jurídica em seu conjunto. Isso ocorre porque, em uma democracia, toda a interpretação do direito constitucional deve considerar a própria democracia. (ABBOUD, 2016, p. 747-748)
}

Assim, por mais complexa que seja a questão jurídica, das inúmeras interpretações suscitadas, sempre haverá uma que será a mais correta. Ela se evidencia por ser pragmática, ter proximidade com o caso concreto, estar concatenada com a atual moralidade política da comunidade e ao conjunto principiológico jurídico, sem qualquer abstração.

Dworkin ao verificar que na abordagem prática "a decisão judicial é vista como acontecimento político" de caráter utilitarista, ele conclui que a resposta mais correta se alcança pela abordagem teórica, na qual "se resolve a questão jurídica mediante uma rede de princípios de natureza jurídica ou moralidade política" (ABBOUD, 2016, p. 750), sem espaços para relativismos e discricionariedade.Abboud sintetiza que para se alcançar a resposta correta no caso concreto, devem ser seguidos os seguintes requisitos mínimos:

(i) Identificar precisamente a factidade ínsita ao caso concreto; (ii) identificar a legalidade aplicável ao caso; (iii) identificar as demais fontes jurídicas positivas aplicáveis ao caso; (iv) Deve haver um resgate da análise teórica do direito, mediante a incidência da fonte não positiva do direito, a doutrina; (v) Deve haver estrita relação de individualização dos pedidos do autor bem como das exceções e dos pontos de defesa do réu; (vi) O julgador deve demonstrar porque a solução proferida por ele é superior às demais, compreendendo a apresentada por uma das partes ou presente em outras decisões; (vii) O julgador, para construir a resposta correta, deve se preocupar com as consequências jurídicas de sua decisão. (2016, p. 763)

A discricionariedade robustece o ativismo judicial, com decisões fundamentadas em concepções particulares e sentimentais (políticas), violando princípios jurídicos (máxime, 
democráticos) e a ordem estatal. Destarte, a adoção da tese da resposta correta com a abordagem teórica nas decisões judiciais é um verdadeiro resgate à análise teórica do direito, limitação do superpoder interpretativo e manutenção da imparcialidade do juiz.

Montesquieu já prelecionava que embora a liberdade política fosse encontrada nos governos moderados, como na democracia, ela apenas existe quando não há abuso de poder.Mas ele mesmo adverte que "trata-se de uma experiência eterna que todo homem que possui poder é levado a dele abusar; ele vai até onde encontra limites" e "para que não se possa abusar do poder, é preciso que, pela disposição das coisas o poder limite o poder. " (2006, p. 166) Afinal, quem controla quem tudo controla?!

Com a aglutinação mascarada das funções precípuas do Legislativo e Executivo para o Judiciário tem-se o risco de unificação dos poderes governamentais. Como bem apresentado pela história da civilização humana e da constituição do Estado quanto mais concentrado o poder, maior o risco da arbitrariedade, muito marcante nas monarquias absolutistas.

No Estado absolutista uma mesma pessoa legisla, executa e julga a seu bel-prazer. A ordem jurídica democrática e os direitos fundamentais restamprejudicados, o povo é governado por um poder ilimitado utilizado para os interesses de um determinado grupo.

Assim, quando o magistrado profere uma sentença (julga) com uma interpretação extremamente inovadora da norma (legisla), obrigando que uma parte da verba pública seja destinada para atender particulares (administra), há a unificação dos poderes em uma única pessoa e a racionalização do poder preconizado pela Constituição desvirtuada. Ludicamente mira-se no lugar da toga, uma coroa no juiz.

Portanto, a atuação judicial precisa ser limitada aos ditames principiológicos e legais para impediruma possível centralização dos poderes maquiada com decisões ativistas, dotadas de arbitrariedade na interpretação da norma constitucional e infralegal e ampliação das funções atípicas.

Barroso adverte que a arrogância do primo americano da judicialização pode ser controlada através da autocontenção judicial.

Por essalinha, juízes e tribunais a) evitam aplicar diretamentea Constituição a situações que não estejam no seuâmbito de incidência expressa, aguardando opronunciamento do legislador ordinário; b) utilizamcritérios rígidos e conservadores para a declaraçãode inconstitucionalidade de leis e atos normativos; e c) abstêm-se de interferir na definição das políticaspúblicas. Até o advento da 
Constituição de 1988, essaera a inequívoca linha de atuação do Judiciário noBrasil. (2012a, p.26)

Destarte, a autocontenção judicial exsurge justamente para reequilibrar a atuação do Judiciário com o Legislativo e o Executivo, devolvendo a independência e harmonia entre os poderes, refutando a reconcentração das funções precípuas do Estado, ou melhordizendo do poder.

\section{CONSIDERAÇÕES FINAIS}

Inspirados na doutrina do Barão de Montesquieu os liberais lutaram pela Teoria da tripartição dos poderes, no qual se desconcentra o poder uno do governante em Executivo, Legislativo e Judiciário. Cada poder é responsável por uma atividade precípua do Estado, limitada pela Constituição e por eles mesmo em razão do checkand balances.

Seguindo, o Estado Social reconhece a necessidade da intervenção do Estado para garantir os direitos da coletividade e que o voto universal é uma expressão da soberania popular e, por conseguinte, do princípio democrático.

Vencido o Golpe Militar de 1964 o Brasil reconhece na Magna Carta de 1988 o Estado Democrático de Direito, amplia o rol de direitos fundamentais, adota os modelos de controle de constitucionalidade direto e indireto, "petrifica" a separação dos poderes, e abre espaço para a jurisdição constitucional. Esta última verifica-se com o fortalecimento do Judiciárioatravés da ampliação da estrutura judicial e das matérias judicializadas, da autonomia financeira e funcional e constitucionalização das garantias dos magistrados. Deriva da jurisdição constitucional os fenômenos da judicialização e do ativismo judicial.

A judicialização reflete a incidência jurisdicional em matérias que antes não eram de sua competência, em razão da Constituição de 1988. Isso porque, qualquer matéria constitucional pode ser objeto de apreciação judicial, seja por um processo particular ou pelos controles de constitucionalidade.

Todavia muitos pleitos que deveriam ser debatidos exclusivamente nas outras instâncias de Poder (Legislativo e Executivo), considerando o caráter eminentemente político e/ou social da matéria, são decididos pelos magistrados, máxime pelos ministros. 
A questão se agrava quando o juiz amplia demasiadamente a interpretação da Constituição e das normas infraconstitucionais no caso concreto, ao ponto de se denotar uma verdadeira inovação normativa, máxime com a avalanche jurisprudencial e sumular. Uma verdadeira conduta ativista judicial que pode conter distorções ao princípio democrático.

Conquanto o magistrado seja o intérprete da lei e da Constituição, ele não é o único. Aliás, a sua função interpretativa deve ser contida nos limites atribuídos pela Carta Maior e pelos princípios jurídicos, pois é o subsídio para a manutenção da ordem política, social e jurídica do Estado e da contenção do uso arbitrário do poder.

Nas questões com caráter político (verbi gracia, políticas públicas) os magistrados utilizam a discricionariedade para sentenciar, notadamente contra os outros poderes, para realizarem suas atividades fins no caso concreto. Porém a fundamentação utilizada pelos juízes contém mais teor político do que propriamente jurídico, interferindo diretamente na atuação dos outros poderes, seja na discricionariedade institucional, planejamento funcional e/ou orçamentário e causando até mesmoprejuízos à segurança jurídica.

É certo que em variadas situações a atitude ativista do Judiciárionão derroga a atividade eminentemente administrativa e legislativa, mas preenche lacunas graves e irresponsáveis pela inércia dos representantes. Mas por vezes tem-se também uma posição de proeminência judicial em relação aos outros poderes, principalmente quando se está a analisar o Supremo Tribunal Federal, prejudicando a manutenção da separação das funções governamentais. Há no Brasil umacrise de legitimidade e de representatividade.

Incontestável que seja direito do cidadão a prestação eficaz dos serviços públicos e da ordem social, entretanto como bem aduz o ditado "os fins não justificam os meios". O ativismo judicial não atribui legitimidade democrática (angariada pelo voto popular) para o magistrado legislar e administrar o país, casuisticamente, nem mesmo capacidade técnica.

Assim, ao lado das benesses do ativismo judicial estão os prejuízos, que nesta constante gangorra, vem pendulando mais do que deveria para o último, resultando no acobertamento das deficiências dos poderes Legislativo e Executivo, enobrecimento do Judiciário, desvirtuação dos limites constitucionais do poder e detrimento do princípio democrático e da legalidade.

A autocontenção judicial deve ser fortalecida no desenho institucional brasileiro para que ocorra o restabelecimento da harmonia entre os poderes, revigoramento do Estado 
Democrático de Direito e o afastamento de uma possível centralização dos poderes governamentais (julgar, legislar e administrar) nas mãos de uma única pessoa ou órgão. O rei não deve retornar, nem mesmo com uma toga.

\section{REFERÊNCIAS}

ABBOUD, Georges. Ativismo judicial e a resposta correta: A intrincada relação da jurisdição constitucional com os demais poderes. Processo Constitucional Brasileiro. São Paulo: Revista dos Tribunais, 2016. Cap. 10. p. 703-763.

BARROSO, Luís Roberto. Constituição, democracia e supremacia judicial: Direito e política no Brasil contemporâneo. O controle de constitucionalidade no direito brasileiro: Exposição sistemática da doutrina e análise crítica da jurisprudência. 7. ed. São Paulo: Saraiva, 2016. p. 381-428.

(a). Judicialização, ativismo judicial e legitimidade democrática.

[Syn]Thesis: Cadernos do Centro de Ciências Sociais, Rio de Janeiro, v. 5, n. 1, p.23-32, jun. 2012. Semestral. Disponível em: <http://www.epublicacoes.uerj.br/index.php/synthesis/article/view/7433>. Acesso em: 26 abr. 2016.

BECHARA, Gabriela Natacha; RODRIGUES, Horácio Wanderlei. Ditadura militar, atos institucionais e Poder Judiciário. Justiça do Direito, Passo Fundo, v. 29, n. 3, p.587-605, set/dez. 2015. Quadrimestral. Disponível em:

<www.upf.br/seer/index.php/rjd/article/download/5611/3581>. Acesso em: 09 mai. 2016.

BONAVIDES, Paulo. Do Estado Liberal ao Estado Social. 8 ed. São Paulo: Malheiros, 2007.

BRASIL. Constituição da República Federativa do Brasil. Brasília: Senado, 1988.

Disponível em:

<http://www.planalto.gov.br/ccivil_03/constituicao/ConstituicaoCompilado.htm>. Acesso em: 12 mai. 2016.

LEAL, Mônica Clarissa Henning; BOLESINA, Iuri. A jurisdição constitucional como defensora da democracia e dos direitos fundamentais no Estado Constitucional e Democrático de Direito. In: Revista Pensar, Fortaleza, v. 17, n. 1, p.273-296, jan/jun 2012. Quadrimestral. Disponível em:

<http://ojs.unifor.br/index.php/rpen/article/viewFile/2284/pdf>. Acesso em: 23 abr. 2016.

MONTESQUIEU, Charles de Secondat. 1689-1755. Das Leis que formam a liberdade política em sua relação com a constituição. In: O espírito das leis. Tradução de Cristina Murachco. 2. ed. São Paulo: Martins Fontes, 2000. Cap. 11. p. 165-196. 
MORAIS JUNIOR, João Nunes. Estado Constitucional de Direito: breves considerações sobre o Estado de Direito. In: Revista de Direito Público, Londrina, v. 2, n. 3, p.119-136, set/dez 2007. Quadrimestral. Disponível em:

<http://www.uel.br/revistas/uel/index.php/direitopub/article/viewFile/11546/10249>. Acesso em: 23 abr. 2016.

NEGRELLY, Leonardo Araujo. O ativismo judicial e seus limites frente ao estado democrático. Conpedi: Anais do XIX Encontro Nacional do CONPEDI, Fortaleza, p.14151428, jun. 2010. Disponível em:

<http://www.publicadireito.com.br/conpedi/manaus/arquivos/anais/fortaleza/3684.pdf>. Acesso em: 27 abr. 2016.

PIMENTEL, Ana Laura Camparini. Ativismo Judicial: Avanço ou deformação do sistema jurisdicional. Projuris: Estudos Jurídicos, Marília, 07 dez. 2012. Disponível em:

$<$ http://projuriscursos.com.br/revista/artigo/17-ativismo-judicial:-avanco-ou-deformacao-dosistema-jurisdicional>. Acesso em: 27 abr. 2016.

SANTOS, Lília Nunes dos. Judicialização e a ADPF no 54: A vida humana como objeto de decisão nos tribunais. In: Conpedi: Teorias da decisão e realismo jurídico, Florianópolis, p.192-213, jan. 2015. Disponível em:

<http://www.conpedi.org.br/publicacoes/c178h0tg/k4yol24r/VorfmQ4az97uzrVa.pdf>. Acesso em: 25 abr. 2016.

SILVA, Ricardo Alves. Ativismo judicial, judicialização e políticas públicas de saúde e a entrega de medicamentos no Distrito Federal. $86 \mathrm{f}$. Monografia (Especialização) - Curso de Pós-graduação em Direito Administrativo, Instituto Brasiliense de Direito Público, Brasília, 2015. Disponível em:

<http://dspace.idp.edu.br:8080/xmlui/bitstream/handle/123456789/1874/Monografia_Ricardo Alves Silva.pdf?sequence=1>. Acesso em: 25 maio 2016.

TEIXEIRA, Rodrigo Valente Giublin; RAVAGNANI, Milton Roberto da Silva Sá. O princípio da proporcionalidade no controle de constitucionalidade. Conpedi: Direito Civil Constitucional, Florianópolis, p.385-409, 2015. Disponível em: <http://www.conpedi.org.br/publicacoes/66fsl345/e703oogw/4924bo32AsfLLwmP.pdf>. Acesso em: 27 abr. 2016. 